\title{
BIOTECH-PHARMACEUTICAL ALLIANCES AS A SIGNAL OF ASSET AND FIRM QUALITY
}

\author{
Sean Nicholson \\ Patricia M. Danzon \\ Jeffrey McCullough \\ Working Paper 9007 \\ http://www.nber.org/papers/w9007
NATIONAL BUREAU OF ECONOMIC RESEARCH 1050 Massachusetts Avenue
Cambridge, MA 02138
June 2002

Financing for this research was provided by a grant from the Merck Foundation, the Leonard Davis Institute for Health Economics, and by the Emerging Technologies Program at The Wharton School. We thank Windhover Information, Recombinant Capital, and Adis for providing data, and Andrew Epstein and Nuno Pereira for their research assistance. The views expressed herein are those of the authors and not necessarily those of the National Bureau of Economic Research.

(C) 2002 by Sean Nicholson, Patricia M. Danzon and Jeffrey McCullough. All rights reserved. Short sections of text, not to exceed two paragraphs, may be quoted without explicit permission provided that full credit, including $\odot$ notice, is given to the source. 
Biotech-Pharmaceutical Alliances as a Signal of Asset and Firm Quality

Sean Nicholson, Patricia M. Danzon and Jeffrey McCullough

NBER Working Paper No. 9007

June 2002

JEL No. I11, L24, L65

\begin{abstract}
Biotechnology companies rely heavily on alliances with pharmaceutical companies to finance their research and development expenditures, and pharmaceutical firms rely heavily on alliances to supplement their internal research and development. Previous studies suggest that asymmetric information may lead to inefficient contracting. We examine the determinants of biotech-pharmaceutical deal prices to determine whether the market for deals between biotech and pharmaceutical companies functions as a well-informed market or whether it is characterized by asymmetric information. We find that inexperienced biotech companies receive substantially discounted payments when signing their first deal. Drugs that are jointly developed are more likely to advance in clinical trials than drugs that are developed by a single company, so the first-deal discount is not consistent with the post-deal performance of these drugs. We also find that biotech companies that sign deals receive substantially higher valuations from venture capitalists and from the public equity market, which implies that the discounts are rational; a biotechnology company that is developing its first product benefits from forming an alliance with a pharmaceutical company because it sends a positive signal to prospective investors.
\end{abstract}

Sean Nicholson

The Wharton School

University of Pennsylvania

3641 Locust Walk

Philadelphia, PA 19104

and NBER

nicholss@wharton.upenn.edu

Tel: 215-898-9403

Fax: 215-573-2157
Patricia M. Danzon

The Wharton School

University of Pennsylvania

3641 Locust Walk

Philadelphia, PA 19104

danzon@wharton.upenn.edu

Tel: 215-898-5722

Fax: 215-573-2157
Jeffrey McCullough

The Wharton School

University of Pennsylvania

3641 Locust Walk

Philadelphia, PA 19104

jmccullo@wharton.upenn.edu

Tel: 215-898-6861

Fax: 215-573-2157 


\section{Introduction}

Biotechnology companies rely heavily on strategic alliances with pharmaceutical companies to finance their research and development (R\&D) expenditures. In 1998, for example, biotech companies raised three times as much ( $\$ 6.2$ billion) from alliances with pharmaceutical companies as from the private and public equity markets combined (Figure 1). The share of biotechnology financing raised through alliances varies with the state of equity markets. For example, in 1994, 1995, 1997, and 1998, when biotech stock prices were relatively low, biotech companies raised more money from pharmaceutical alliances than from all other sources combined. However, the continual flow of alliances even in years when the public equity windows are "open," such as 1999, suggests that alliances with pharmaceutical firms create value rather than functioning merely as a source of financing.

There has been considerable theoretical work in the economics and strategy literature examining why firms enter joint ventures (summarized by Kogut, 1988). The basic theory of the firm implies that firms will form alliances when other firms have comparative advantage in certain functions. In the case of the biotech-pharmaceutical industry, small biotech firms have pioneered new drug discovery technologies, which rely on microbiology and genomics, whereas traditional pharmaceutical companies have superior expertise in chemistry, which is essential for the formulation of drugs from the lead compounds generated by drug discovery. Pharmaceutical companies generally are larger, have more experience and possibly economies of scale and scope in conducting clinical trials for safety and efficacy, navigating the Food and Drug Administration (FDA) approval process, manufacturing, and marketing and sales. Biotech-pharmaceutical deals may thus be viewed as a vehicle through which the parties exchange services, given their different skills and expertise.

Large pharmaceutical companies are relying increasingly on alliances to supplement their drug pipelines. Of the 691 new chemical entities approved by the FDA between 1963 and 1999, 38 percent were in-licensed (DiMasi, 2000). In Figure 2 we report the number of biotech alliances signed by the 20 
largest pharmaceutical firms between 1988 and 1998. ${ }^{1}$ The average number of biotechnology alliances signed per pharmaceutical firm per year increased from 1.4 in 1988-1990 to 5.7 in 1997-1998. Earlystage (discovery) deals far outnumber deals for compounds in later stages of development. In 1997 and 1998, for example, discovery deals outnumbered middle-stage (preclinical and phase 1) deals by seven to one, and late-stage (phase 2 and phase 3 ) deals by four to one. The preponderance of early stage deals may reflect the fact that there are simply more products at early stages, before attrition for scientific or economic reasons. However, the preponderance of early stage deals is also consistent with the hypothesis that the incremental value from co-development is greatest if alliances are formed early in a drug's life. ${ }^{2}$

An alternative, not mutually exclusive body of theory focuses on imperfect information and the role of financial intermediaries that can evaluate and signal to markets the quality of other firms (Chemmanur and Fulghieri, 1994; Chemmanur, 1993; Chan, 1983; Campbell and Kracaw, 1980; and Leland and Pyle, 1977). Pharmaceutical firms can be viewed as performing a similar validating function. If investors (venture capitalists and investment bankers) have less information than pharmaceutical firms regarding the likely success of a biotech firm's products and the quality of its science and management, then by doing a deal with a pharmaceutical firm, a biotech firm can signal its quality to financial markets. If so, inexperienced biotech firms that can benefit most from such validation should be willing to pay for it in the form of a discount on their products, to be recouped by a subsequent increase in their market valuation when they next raise private or public equity capital.

Previous literature on biotech-pharmaceutical alliances has been largely empirical and provides mixed evidence on the efficiency of this market and the extent of imperfect information. Lerner and Merges (1998) examine the allocation of property rights in biotech-pharmaceutical alliances, testing the

\footnotetext{
${ }^{1}$ The data in Figure 2 are from Recombinant Capital and include certain types of deals (e.g. platform technology deals) that are excluded from the sample used in our regression analysis. The number of deals by stage in Figure 2 is therefore different from Table 1.

${ }^{2}$ The greater number of late than middle stage deals and their relatively low payments is a puzzle (see Longman and Roche, 1997). One possible hypothesis to explain this apparent bias against middle stage deals is that corporate structures lack a "champion" for middle stage deals. If such bias persists, it implies significant, unexploited profit opportunity for companies that seek out undervalued middle stage deals. However, the conclusions on bias in
} 
theory developed by Aghion and Tirole (1994), who argue that property rights (e.g., responsibility for managing the clinical trials or for manufacturing the product) should be assigned to the R\&D firm when the marginal impact of its effort on the product's value is greater than the marginal impact of the licenser firm's financial investment on the product's value. Lerner and Merges find evidence that biotech firms with more financial resources retain a relatively large amount of the property rights, which appears to be consistent with efficient allocation of rights. However, Lerner and Tsai (2000) find that deals signed during periods when it is difficult for biotech firms to raise public or private equity assign most of the property rights to the licensee (usually a pharmaceutical firm), and these alliances are less likely to lead to a drug approved by the FDA. This appears to suggest inefficiency in the allocation of rights, presumably resulting from imperfections in the market for financing biotech deals. ${ }^{3}$ Pisano (1997) finds that drugs developed by biotech-pharmaceutical collaborations are less likely to reach the market than drugs developed by a single firm, which leads him to conclude that biotech companies use their informational advantage to outlicense their low-quality products. This suggests a different type of inefficiency - a persistent information asymmetry between biotech and pharmaceutical firms that leads to a quasi-lemons phenomenon in the market for deals.

None of these previous studies have examined how the magnitude of biotech-pharmaceutical deal payments vary with the characteristics of the product, characteristics of the buyer and seller firms, and the state of equity markets - the principal alternative source of financing biotech R\&D. Furthermore, we are aware of no studies that examine whether these deals increase the market value of biotech firms as suggested by a model of asymmetric information and signaling.

The objective of this paper is to determine whether the market for deals between biotech and pharmaceutical companies functions as a well-informed market or whether it demonstrates evidence of asymmetric information and, if so, to examine the nature and magnitude of any biases. We use data on

payment levels do not factor in differences in costs and risks by stage of deal, and recent trends suggest that any prior bias may no longer exist. These issues are the subject of ongoing work. 
the prices of 539 deals from the Windhover Database of Strategic Alliances for the period 1988-2000. Data on product and firm characteristics are from the Adis International R\&D Insight Database, Recombinant Capital, and Compustat. We begin by examining the association between deal payments, measured by total pre-commercial payments for inlicensed drugs, and characteristics of the product (stage of development and therapeutic class) and rights transferred; characteristics of the parties to the transaction, such as the biotech firm's prior experience negotiating deals and the size of the buying firm; and the expected cost of alternative financing, through public and private equity.

We then examine the effect of deals on the valuation of biotech firms in subsequent rounds of venture capital and public equity financing. If pharmaceutical firms are better able than the financial markets to evaluate the scientific and managerial expertise of private biotech companies, then biotech firms that sign deals should receive higher valuations than otherwise similar firms that develop their drugs independently, due to the positive signal provided by an alliance with an established pharmaceutical firm. If, on the other hand, venture capitalists and investment bankers are as capable as pharmaceutical firms at evaluating biotech companies and their products, then deals should have little effect on the private or public market value of biotech firms, assuming that deal payments reflect the expected net present value of rights transferred by the biotech to the pharmaceutical firm.

In our final analysis we test for information asymmetries in the deals market by examining whether drugs that are developed in a biotech-pharmaceutical alliance are in fact less likely to succeed in clinical trials than drugs that are developed by a single biotech firm. If so, this would tend to confirm the "lemons" hypothesis suggested by the findings in Pisano (1997): biotech firms exploit their information advantage about the quality of their drug candidates by outlicensing to pharmaceutical firms those that have relatively poor prospects.

Our main finding in the analysis of deal prices is that biotechnology companies signing their first deal receive a 60 percent discount relative to firms that have signed at least two prior deals, controlling

\footnotetext{
${ }^{3}$ An efficient approach would presumably adjust the size of deal payment, not the allocation of rights, if relative bargaining power shifts; however, this assumes that financing is available from other sources at an appropriate risk-
} 
for product characteristics and some measure of rights transferred, and that this discount is not consistent with the post-deal performance of the drug. Thus unlike Pisano (1997), we find no evidence that outlicensed products are "lemons." The market valuation analysis shows that biotechs are able to recoup this first-deal discount in subsequent financing rounds with either venture capitalists or in initial public offerings. The discount for inexperience declines to 30 percent on a biotech firm's second deal and is insignificant for subsequent deals. Thus these findings are consistent with asymmetric information in financial markets, such that pharmaceutical companies are better able than money managers to evaluate the scientific and managerial expertise of private biotech firms. Consequently, biotech companies are willing to make implicit payments (by accepting lower deal payments) for the validation provided by a deal with a large pharmaceutical company, and this payment is recouped through a higher subsequent market valuation. However, the fact that alliances occur even between well-established biotech and pharmaceutical firms suggests that signaling is not the sole function of biotech-pharmaceutical alliances; deals on average create positive incremental value due to the exchange of different skills. We attempt, to the extent possible, to distinguish the signaling and the value-added motivation for deals.

\section{Models of the Market for Deals Between Biotech and Pharmaceutical Companies}

\section{a) Perfect information: the gains-from-trade model of deals}

To provide a benchmark for deal valuations in the absence of imperfect information, it is helpful to begin by characterizing a well-functioning market for deals, which would include: many potential sellers (usually -- and hereafter -- biotech companies) of promising drug candidates, many potential buyers (usually -- and hereafter -- pharmaceutical companies) for any drug candidate; symmetric information regarding the quality of the drugs and partnering capabilities of firms, between biotech companies, pharmaceutical companies, venture capitalists and other money managers; and no liquidity constraints (for example, due to the sector falling out of favor) so that biotech companies are able to raise sufficient capital to fund $R \& D$ at appropriately risk-adjusted rates. In such conditions, potential buyers

adjusted rate. 
and sellers would separately calculate the value of a drug as the discounted present value of its expected cash flows.

The expected net present value $\left(\mathrm{V}_{0}\right)$ of a drug that is currently in the preclinical stage $(0)$, assuming that it will be developed by the biotech company that originated the drug is:

$$
\left[V_{0} \mid d=0\right]=\frac{\mathrm{p}_{0} \mathrm{p}_{1} \mathrm{p}_{2} \mathrm{p}_{3} \mathrm{R}}{(1+r)^{4}}-\left[C_{0}+\frac{p_{0} C_{1}}{1+r}+\frac{p_{0} p_{1} C_{2}}{(1+r)^{2}}+\frac{p_{0} p_{1} p_{2} C_{3}}{(1+r)^{3}}\right]
$$

where the subscripts $0,1,2$, and 3 refer to the preclinical, phase 1 , phase 2 , and phase 3 development stages, $\mathrm{d}$ is an indicator variable that equals one if a drug is developed jointly by a biotech and pharmaceutical firm under an alliance, $\mathrm{p}$ is the phase-specific probability a drug advances from a particular stage, $\mathrm{C}$ is the phase-specific $\mathrm{R} \& \mathrm{D}$ cost, $\mathrm{R}$ is the value of the commercial cash flows (net of manufacturing, marketing costs and any post-launch R\&D expenses) discounted to the first year of sales, and $\mathrm{r}$ is the discount rate. Each development stage is assumed to last one year for sake of simplicity, although in reality the mean duration varies by development stage. Values of $\mathrm{p}, \mathrm{C}$ and $\mathrm{R}$ may differ across firms, due to differing expertise.

If this drug advances to phase 1 , its value $\left(\mathrm{V}_{1}\right)$ becomes:

$$
\left[V_{1} \mid d=0\right]=\frac{\mathrm{p}_{1} \mathrm{p}_{2} \mathrm{p}_{3} \mathrm{R}}{(1+r)^{3}}-\left[C_{1}+\underline{p_{1} C_{2}}+\frac{p_{1} p_{2} C_{3}}{1+r}\right]
$$

$\mathrm{V}_{1}$ exceeds $\mathrm{V}_{0}$ for three reasons. First, as a drug advances from discovery to clinical trials to regulatory approval, the scientific risk that it will fail safety and efficacy tests decreases, and hence the probability increases that it will be commercialized. Second, projected revenues become more imminent as commercialization approaches and are, therefore, discounted less heavily. Third, as a drug develops more $R \& D$ costs become sunk. $V_{0}$ and $V_{1}$ as defined in equation 1 and equation 2 can be viewed as the reservation price or the minimum asking price of a seller, substituting its specific values for all the parameters. 
Consider now the maximum amount that a pharmaceutical company would be willing to pay for this drug, assuming that it would assume all subsequent costs. If the pharmaceutical company has the same probabilities, revenue, and cost estimates as the biotech company, $\mathrm{V}_{1}$ also reflects the amount that the buyer/pharmaceutical company would be willing to pay for this drug in phase 1 . With competitive entry into the development of drug candidates, the initial expected net present value $\left(\mathrm{V}_{0}\right)$ for the marginal drug should be zero. The expected net present value of a phase one product $\left(\mathrm{V}_{1}\right)$ is positive by an amount that reflects the costs and risk already incurred by the biotech company. Similarly, $\mathrm{V}_{2}$ for a phase 2product would be higher by an amount that reflects the additional costs that are sunk and the incremental probability the drug will be commercialized. Thus, under the assumptions of symmetric information, the value of deals signed at successive phases should increase by an amount that reflects the incremental costs and risks incurred. This conclusion assumes no difference in assignment of rights, in the type of products involved, or in the structure of deals by stage of development. ${ }^{4}$

With identical costs and capabilities between firms there would be no rationale for doing deals, even with perfect information. The gains-from-trade or comparative advantage theory of deals assumes that if an experienced pharmaceutical firm works with a biotech company some of the development costs will be lower and/or expected revenues will be higher. In particular, a pharmaceutical firm may potentially increase $\mathrm{p}$ due to greater experience in managing clinical trials, decrease $\mathrm{C}$ due to economies of scale and scope, or increase $\mathrm{R}$ due to its large and experienced sales force. In that case, the value of a phase 1 drug if co-developed by the pharmaceutical firm $\left(\mathrm{V}_{1} \mid \mathrm{d}=1\right)$ exceeds its value if developed solely by the biotech firm $\left(V_{1} \mid d=0\right)$. The actual deal payment will be between $V_{1} \mid d=1$ and $V_{1} \mid d=0$ depending on the how the incremental value of co-development is shared, which in turn depends on the relative bargaining power of the parties.

\footnotetext{
${ }^{4}$ Deal payments may also vary by stage of deal if the assignment of responsibilities, rights, and costs differ by deal stage. For example, for pre-development deals (prior to the start of human clinical trials) a pharmaceutical company may incur some or all of the costs of clinical trials and would usually bear most manufacturing and marketing costs. If the deal is signed late in phase 3 , however, the biotech company has already built substantial manufacturing capability and may participate in post-launch manufacturing and marketing, sharing some of these costs in return for a larger share of drug revenues.
} 
The profit-maximizing strategy for a biotech firm with a promising drug candidate is to develop the drug in-house or select a stage of development (e.g., preclinical) in which to sign a deal with a pharmaceutical firm, according to which alternative yields the highest discounted present value. The gains-from-trade model predicts that a necessary condition for a biotech firm to sign a preclinical deal and share responsibilities for developing the drug with a pharmaceutical firm is that the expected value of the drug in a biotech-pharmaceutical collaboration $\left(\mathrm{V}_{0} \mid \mathrm{d}=1\right)$ exceeds the expected value of the drug if developed independently by the biotech company $\left(\mathrm{V}_{0} \mid \mathrm{d}=0\right)$, and exceeds the expected value of the drug if a deal were signed at a later development stage $\left(\mathrm{V}_{1}\left|\mathrm{~d}=1, \mathrm{~V}_{2}\right| \mathrm{d}=1\right.$, and $\left.\mathrm{V}_{3} \mid \mathrm{d}=1\right){ }^{5}$

In the perfect information model, when a biotech firm signs a deal with a pharmaceutical firm there should be no effect on the biotech's market value. Venture capitalists and other investors should be able to anticipate the positive incremental value of co-development and incorporate this value at the previous financing round.

\section{b) Imperfect information: the signaling model of deals}

We now relax the assumptions of a well-functioning market for biotech-pharmaceutical deals and analyze the implications of market imperfections on the type of deals, deal payments, and the performance of drugs developed in biotech-pharmaceutical alliances versus independently developed drug candidates. Consider first asymmetric information: prospective buyers of drug candidates (pharmaceutical firms) and investors (venture capitalists) may have less information than prospective sellers (biotech companies) regarding the quality of a biotech company's drugs and the competence of its management. This information asymmetry could be particularly severe when drugs are in the preclinical phase, before empirical evidence on the drug's safety and clinical efficacy are available.

\footnotetext{
${ }^{5}$ This is a necessary not a sufficient condition for a deal if some potential deals fail due to disagreement over sharing the incremental value from co-development. It is also possible that biotech companies accept less than the value-maximizing terms on one drug, in order to participate in on-the-job training from sharing manufacturing and/or marketing with an experienced pharmaceutical firm.
} 
We adapt to the biotech-pharmaceutical setting a model that Campbell and Kracow (1980) use to explain the role of financial intermediaries as signalers of high-quality firms. Specifically, we assume there are high-quality $(\mathrm{H})$ and low-quality $(\mathrm{L})$ biotech firms that produce high- and low-quality drug candidates, respectively. ${ }^{6}$ The expected discounted net present value of a high-quality drug exceeds that of a low-quality drug at all development stages $\left(\mathrm{V}_{\mathrm{H}}>\mathrm{V}_{\mathrm{L}}\right)$ due to superior scientific characteristics and/or superior managerial skill or effort. Biotech firms know the quality of their drug candidates but cannot convey this information credibly to prospective buyers (pharmaceutical firms) and equity investors. If there is no mechanism to signal quality the only possible equilibrium is a pooling equilibrium: highquality and low-quality biotech firms are both valued at $\underline{\mathrm{V}^{\mathrm{F}}}$ rather than the values commensurate with the quality of their drug portfolios, $\mathrm{V}^{\mathrm{F}}{ }_{\mathrm{H}}$ and $\mathrm{V}_{\mathrm{L}}^{\mathrm{F}}$. Here the superscript " $\mathrm{F}$ " refers to the firm as a whole, so $\mathrm{V}^{\mathrm{F}}$ is the sum of the expected value of all drugs in a firm's portfolio as determined by the equity investors.

Although high-quality biotech firms would be willing to pay an amount up to $\mathrm{V}_{\mathrm{H}}^{\mathrm{F}}-\underline{\mathrm{V}^{\mathrm{F}}}$ to have their quality identified, Grossman (1976) and Grossman and Stiglitz (1976) have shown that there may be insufficient incentives to invest in information production in markets with asymmetric information regarding asset quality. When information is a public good and is incorporated instantly into the market prices of the assets in question, the organization incurring the cost of distinguishing high-and low-quality assets is unable to appropriate the benefits of information production because the values of high-quality assets rise when they are identified as such. Furthermore, even if high-quality biotech firms could make side payments to compensate the signaling firm for information production costs, there remains a moral hazard problem: the signaling firm could collect the payment without actually spending the money to produce accurate information unless there is an effective commitment device.

The market for deals between biotech and pharmaceutical firms appears to offer a mechanism by which biotech firms can compensate pharmaceutical firms for their information production costs and pharmaceutical firms will have incentives to be truthful. When pharmaceutical firms license drugs from

\footnotetext{
${ }^{6}$ The qualitative predictions of this model would be the same if we adopted a more realistic assumption that highand low-quality firms generate drugs from two different quality distributions rather than drugs with different
} 
biotech firms and agree to share the development costs and revenues, they have an incentive to evaluate the quality of the asset they are acquiring, which mitigates, if not eliminates, the moral hazard problem regarding information production. ${ }^{7}$ The market for deals also allows biotech firms a means of compensating pharmaceutical firms for the cost of producing information by allowing pharmaceutical firms to subtract the information production costs from their deal payments.

There have been a number of theoretical studies in the finance literature on the role of intermediaries in signaling firm quality, but to our knowledge none of the theories have been tested empirically. Leland and Pyle (1977) argue that the appropriability and moral hazard problems “...can be overcome if the firm gathering the information becomes an intermediary, buying and holding assets on the basis of its specialized information." This seems to describe exactly the role of pharmaceutical firms in searching for drugs to inlicense. In their model, the signal of a firm's quality is the fraction of equity retained by the entrepreneur. In Campbell and Kracow (1980) the moral hazard problem is resolved if the information-producing intermediary has a sufficiently large stake in the market, and thus has incentives to invest an efficient amount in information production and to report truthfully. Chemmanur (1993) argues that high-value firms will compensate investment banks for their information production costs by underpricing their initial public offering, and investment banks will have incentives to generate credible information to maintain their reputation (Chemmanur and Fulghieri, 1994). Finally, Chan (1983) shows that the presence of an informed intermediary can affect the quality of assets in the market and increase social welfare rather than merely re-distributing wealth from over-valued firms to under-valued firms.

Applying these models, assume that pharmaceutical firms and venture capitalists incur search costs, S, to discern a drug's expected net present value, and these costs can vary by stage of development. Pharmaceutical firms are assumed to have a comparative advantage in information production due to their

\footnotetext{
discrete quality measures.

${ }^{7}$ Full elimination of incentives for under investment in information by the signaling firm would require outright purchase of the asset, but this might increase moral hazard by the seller. The fact that deals generally stipulate that the parties share costs and revenues could be a second best way to deter moral hazard by both parties; it also suggests that gains from collaboration outweigh the suboptimal incentives and moral hazard created by sharing contracts.
} 
superior scientific and commercial knowledge relative to venture capitalists and other investors. Part of S is dedicated to identifying the competence of the biotech company's management, since the biotech will be integral to the development of the drug, and part to identifying the quality of the specific drug in question. The former cost will be incurred only as long as it takes prospective buyers to discern a firm's managerial quality, while the latter cost will occur with each deal. We consider four different scenarios regarding the incremental value of co-development relative to the cost of producing information, and the magnitude by which high-quality biotech firms are undervalued in a pooling equilibrium.

In the first scenario, the incremental value of co-development for high- and low-quality drugs $\left(V_{H}\left|d=1-V_{H}\right| d=0\right.$ and $\left.V_{L}\left|d=1-V_{L}\right| d=0\right)$ exceeds $S$, so both high- and low-quality biotech firms will sign deals with pharmaceutical firms. If there are a large number of prospective buyers relative to sellers, high-quality biotech firms will receive payments of $\mathrm{V}_{\mathrm{H}} \mid \mathrm{d}=1-\mathrm{S}$, and low-quality firms will receive payments of $\mathrm{V}_{\mathrm{L}} \mid \mathrm{d}=1-\mathrm{S} .{ }^{8}$ A biotech firm that is considered by pharmaceutical firms to be high quality should receive higher payments from subsequent deals (relative to its first deal) because it only needs to compensate the pharmaceutical firm for the drug-specific information production costs. The number of deals required to signal a firm's quality type is an empirical question that we will examine.

Although both types of biotech firms sign deals, we assume there will still be a separating equilibrium because venture capitalists are able to identify the quality of a biotech firm from the magnitude of the deal payment. That is, we assume venture capitalists can distinguish $\mathrm{V}_{\mathrm{H}} \mid \mathrm{d}=1-\mathrm{S}$ from $\mathrm{V}_{\mathrm{L}} \mid \mathrm{d}=1$ - $\mathrm{S}$. As a result, biotech firms will be valued at their appropriate levels $\left(\mathrm{V}^{\mathrm{F}}{ }_{\mathrm{H}}\right.$ and $\left.\mathrm{V}^{\mathrm{F}}{ }_{\mathrm{L}}\right)$ in the financing round (either follow-on venture capital financing or an initial public offering) following a deal. The market value of high-quality biotech firms would increase by $\mathrm{V}_{\mathrm{H}}^{\mathrm{F}}-\underline{\mathrm{V}^{\mathrm{F}}}$ following a deal and the market value of low-quality biotech firms would decrease by $\underline{\mathrm{V}^{\mathrm{F}}}-\mathrm{V}^{\mathrm{F}}$. Low-quality firms will not develop their drugs independently if venture capitalists know the incremental value of co-development is large enough to compensate a pharmaceutical firm for its search costs. If a low-quality biotech forgoes 
signing a deal to try to maintain its overvalued status, the venture capitalists will infer the biotech firm has low-quality drugs. Knowing this, the biotech will sign co-development deals and incur the reduction in value.

In the second scenario we assume that $\left(\mathrm{V}_{\mathrm{H}}\left|\mathrm{d}=1-\mathrm{V}_{\mathrm{H}}\right| \mathrm{d}=0\right)>\mathrm{S}>\left(\mathrm{V}_{\mathrm{L}}\left|\mathrm{d}=1-\mathrm{V}_{\mathrm{L}}\right| \mathrm{d}=0\right)$. A pharmaceutical firm's cost of evaluating an inexperienced biotech company exceeds the incremental value of co-development for low-quality drugs but is less than the incremental value of co-development for high-quality drugs. Only high-quality biotech firms will be able to compensate pharmaceutical firms for the search costs, so only high-quality firms will sign deals and will receive payments of $V_{H} \mid d=1-S$. ${ }^{9}$ The market value of high-quality biotech firms would increase by $\mathrm{V}_{\mathrm{H}}^{\mathrm{F}}-\underline{\mathrm{V}^{\mathrm{F}}}$ following a deal, and the value of biotech companies that have a drug candidate but do not sign a deal falls by $\underline{\mathrm{V}^{\mathrm{F}}}-\mathrm{V}_{\mathrm{L}}^{\mathrm{F}}$.

The third scenario is similar to the second scenario: $\left(\mathrm{V}_{\mathrm{L}}\left|\mathrm{d}=1-\mathrm{V}_{\mathrm{L}}\right| \mathrm{d}=0\right)<\mathrm{S} ;\left(\mathrm{V}_{\mathrm{H}}\left|\mathrm{d}=1-\mathrm{V}_{\mathrm{H}}\right| \mathrm{d}=0\right)<$ $\mathrm{S}$; and $\left(\mathrm{V}_{\mathrm{H}}\left|\mathrm{d}=1-\mathrm{V}_{\mathrm{H}}\right| \mathrm{d}=0\right)+\left(\mathrm{V}_{\mathrm{H}}^{\mathrm{F}}-\underline{\mathrm{V}^{\mathrm{F}}}\right)>\mathrm{S}$. Pharmaceutical search costs are larger than the incremental value of co-development, but high-quality biotech firms are able to compensate pharmaceutical firms from the subsequent increase in value they will receive once venture capitalists receive the quality signal. As in scenario 2, only high-quality firms sign deals and firms are correctly valued at the next financing round. Note that if there are imperfections in the capital market, high-quality biotech firms might not be able to borrow money to fully compensate pharmaceutical firms for their search costs, preventing the formation of alliances that would create value.

In the final scenario no deals will be signed because $\left(\mathrm{V}_{\mathrm{L}}\left|\mathrm{d}=1-\mathrm{V}_{\mathrm{L}}\right| \mathrm{d}=0\right)<\mathrm{S} ;\left(\mathrm{V}_{\mathrm{H}}\left|\mathrm{d}=1-\mathrm{V}_{\mathrm{H}}\right| \mathrm{d}=0\right)<$ $\mathrm{S}$; and $\left(\mathrm{V}_{\mathrm{H}}\left|\mathrm{d}=1-\mathrm{V}_{\mathrm{H}}\right| \mathrm{d}=0\right)+\left(\mathrm{V}_{\mathrm{H}}^{\mathrm{F}}-\underline{\mathrm{V}^{\mathrm{F}}}\right)<\mathrm{S}$. Although this scenario is clearly not borne out in the market because we observe many deals, it highlights another way that information costs could affect the market for biotech-pharmaceutical alliances. In scenario 2 and scenario 3, low-quality biotech firms continue to

\footnotetext{
${ }^{8}$ Later we discuss the possibility that the gains from co-development may accrue wholly or in part to the pharmaceutical firm, if there are few buyers relative to sellers, so the biotech firms receive payments of $V_{L} \mid d=0-S$ rather than $\mathrm{V}_{\mathrm{L}} \mid \mathrm{d}=1-\mathrm{S}$.

${ }^{9}$ The payment to the biotech firm may be somewhat less than $\mathrm{V}_{\mathrm{H}} \mid \mathrm{d}=1-\mathrm{S}$ if the pharmaceutical firm has to incur some search costs in order to determine that a firm/product is high value. The lower payment to high-quality firms would compensate the pharmaceutical firm for the risk that a firm will turn out to be low-quality.
} 
develop their drugs independently rather than sign co-development deals due to the high information costs. It is possible that the cost to pharmaceutical firms of identifying the quality of a drug (and the quality of a biotech firm) might be substantially smaller once the drug has completed phase 1 or phase 2 trials and more information is available regarding the drug's composition and performance. For example, consider a situation where $\left(\mathrm{V}_{\mathrm{L}, 0}\left|\mathrm{~d}=1-\mathrm{V}_{\mathrm{L}, 0}\right| \mathrm{d}=0\right)<\mathrm{S}_{0}$ when a drug is in the preclinical stage, but once the drug reaches phase 2 trials $\left(\mathrm{V}_{\mathrm{L}, 2}\left|\mathrm{~d}=1-\mathrm{V}_{\mathrm{L}, 2}\right| \mathrm{d}=0\right)>\mathrm{S}_{2}$, where the subscripts 0 and 2 refer to the preclinical stage and stage 2 , respectively. In this case we would expect the quality of drugs involved in later-stage deals to be lower than the quality of drugs involved in preclinical deals. Later-stage deal payments would appear to be biased downward in a naïve analysis, but this would be due in fact to unmeasured quality. This model predicts that companies signing their first deal on a late-stage drug (e.g., Phase 2 or Phase 3) would receive relatively low payments, due to low unmeasured quality.

In the empirical analysis we will attempt to identify whether the actual market for deals is consistent with scenario 1 or scenario 2 and scenario 3 (which are empirically indistinguishable); scenario 4 is clearly rejected by the evidence on number of deals. One method of distinguishing the scenarios is to examine the impact of deals on biotech company valuations. If scenario 1 prevails (information costs are less than the benefits of co-development for both high and low quality firms), both types of companies will sign deals. The effect of a deal on a biotech company's valuation would be ambiguous; it depends on the proportion of biotech companies that are high-quality, and the magnitude of the over- versus the under-valuation in the pooling equilibrium. In scenario $2 / 3$ only high-quality firms sign deals, which causes investors to bid up the value of high-quality firms from $\underline{V^{\mathrm{F}}}$ to $\mathrm{V}_{\mathrm{H}}^{\mathrm{F}}$. Thus a positive relationship between a deal and subsequent appreciation in a company's value is a necessary but not sufficient condition to prove the relevance of scenario $2 / 3$.

Another way to distinguish scenario 1 from scenario 2/3 is to examine differences in deal payments according to the stage of a drug's development. If search costs exceed benefits of codevelopment for at least some firms, low-quality drugs are more likely to be outlicensed at later stages of 
development when information costs are lower than in the preclinical stage. Deal payments involving drugs in later stages of development should therefore be relatively low due to unmeasured drug quality. The data prevent us from testing this hypothesis conclusively, but we present some tentative evidence on the issue.

In all scenarios of the signaling model, payments to a biotech firm for its first deal will be relatively low to compensate the pharmaceutical firm for the cost of producing information on the capabilities of the biotech firm's management, in addition to the quality of the drug. It is an empirical question whether one deal is sufficient to signal the biotech firm's managerial capabilities to the market of prospective buyers, or whether subsequent deal payments will also be relatively low. An alternative, and not necessarily mutually exclusive, explanation for a first-deal discount is that biotech firms learn; codevelopment with a pharmaceutical firm adds more value for relatively inexperienced biotech firms. If pharmaceutical firms capture most of the incremental value of co-development due strong bargaining power, then deal payments will be relatively small for inexperienced biotech firms.

In both the gains-from-trade and signaling models, deals occur only after a pharmaceutical firm has invested in information regarding the quality of the biotech company and the drug. These models predict, therefore, that there will be no lemon's problem: biotech firms are not able to outlicense their inferior products. We test this prediction by examining whether drugs outlicensed by biotech firms are less likely to complete clinical trials and be approved by the FDA relative to drugs that biotech firms decide to develop independently.

The imperfect information model thus far has focused on asymmetric information. Another possible imperfection in the market for deals is market power due to small numbers. Specifically, there may be few buyers relative to sellers for the more numerous pre-clinical drugs and few sellers relative to potential buyers for late stage products, due to the high attrition rate of drug candidates and/or inadequate planning by buyers. Moreover, buyers of late stage deals may have more inelastic demand if product failures lead to gaps in a pharmaceutical firm's product pipeline that it urgently needs to fill. If sellers 
have greater bargaining power relative to buyers for late stage products than for early stage products, due to shifts in number of participants, this would lead to relatively high prices for late stage deals, even after adjusting for differences in cost and risk.

Another possibility we examine is that imperfections in the capital market may create imperfections in the market for deals. Deals and equity are alternative sources of financing R\&D, so biotech firms will presumably select the least expensive financing source given the conditions in the two markets. In periods when the public and private equity markets are "closed", deal values might be lower than in periods when it is relatively easy and inexpensive for biotechs to raise private and public equity.

Figure 1 presents data on the amount of public and private equity raised by biotechnology companies between 1991 and 1999. Three times during this period - 1991, 1996, and 1999 - investors were attracted to the biotechnology industry and these companies were able to raise a substantial amount of public equity for R\&D. However, there were also periods when the industry was out of favor and it was difficult or extremely costly for biotech firms to raise equity financing. At such times, alliances with pharmaceutical companies may be a relatively attractive way of raising money for R\&D. The data in Figure 1 support this hypothesis; total alliance funding is relatively high when total equity funding is relatively low. In years when the public equity market is tight, the supply of deals increases, and one would expect the mean deal price to decrease, other things equal. This prediction may be offset if the biotech firms are forced to sign deals on their highest quality drugs during tight equity markets in order to finance their R\&D.

If imperfections in the financial markets create liquidity constraints, a biotech company with a weak balance sheet might be forced to accept early-stage offers because it lacks the financial resources to develop a drug independently. To test this, we include in the empirical analysis the financial strength (measured as the value of equity plus debt) of the biotech company. Our hypothesis is that, controlling for drug characteristics, deal payments will vary inversely with the market value of the biotech company. 


\section{Empirical Method}

\section{a) Determinants of Deal Payments}

We examine the determinants of the deal prices for drugs that are sold or licensed, usually from biotech to pharmaceutical companies, to see if inexperienced biotech firms implicitly pay pharmaceutical firms for the cost of producing information, and whether prices are affected by other possible market imperfections. Equation (1) implies that deal prices must be adjusted for variations in scientific risk and development costs by stage of development, and for expected revenues, which depend on the size and competitive structure of the target market. Using ordinary least squares, we regress the price $\left(\mathrm{P}_{\mathrm{ij}} \mathrm{t}\right)$ that firm $\mathrm{j}$ receives by licensing drug compound $\mathrm{i}$ in year $\mathrm{t}$ on product characteristics and the structure of the deal $\left(\mathbf{X}_{\mathbf{i}}\right)$, characteristics of the selling firm $\left(\mathbf{F}_{\mathbf{j}}\right)$, characteristics of the buying firm $\left(\mathbf{F}_{\mathbf{k}}\right)$, and characteristics of the equity market for biotech firms $(\mathbf{M})$ at the time of the deal $(\mathrm{t})$ :

$$
\log \left(\mathrm{P}_{\mathrm{ijt}}\right)=\gamma_{0}+\gamma_{1} \mathbf{X}_{\mathrm{i}}+\gamma_{2} \mathbf{F}_{\mathrm{jt}}+\gamma_{3} \mathbf{F}_{\mathbf{k t}}+\gamma_{\mathbf{4}} \mathbf{M}_{\mathrm{t}}+\varepsilon_{\mathrm{ijt}}
$$

We include in $\mathbf{X}$ indicator variables for the therapeutic class (a rough proxy for market size and any other class-specific costs or risks) of the drug and indicator variables for the drug's development stage at the time of the deal (discovery/pre-clinical, phase 1, phase 2, phase 3). We also include separate indicator variables if the seller (biotech firm) retained commercial rights to the drug for the U.S. or Japanese markets, whether the buyer (pharmaceutical firm) purchased equity in the seller firm as part of the deal, and for reverse licensing deals. ${ }^{10}$

We include in $\mathbf{F}_{\mathrm{jt}}$ a series of indicator variables to measure the seller's experience, using the number of deals the seller has signed prior to the deal being examined. The coefficients on these indicator variables (e.g., biotech has signed one prior deal, or biotech has signed two prior deals) in the

\footnotetext{
${ }^{10}$ The data available to us are insufficient to estimate a complete model, which would treat the rights transferred and the stage of the drug at the time of the deal as simultaneously determined with the deal payment. We assume here that these other deal terms are predetermined. Our estimates thus reflect deal values conditional on these other deal characteristics.
} 
signaling model measure the decline in S, the pharmaceutical firm's cost of evaluating the net present value of a drug, as information accumulates in the market about the biotech firm's managerial capabilities. In the gains-from-trade model, the experience variables measure the change in the incremental value of co-development synergies as a biotech firm learns.

Conditional on prior deal experience, a small selling firm might be willing to accept a lower deal price if it stands to gain considerably from the experience or the positive signal associated with an alliance, particularly if the licensee is a large established firm. A large buying firm might be able to negotiate lower deal prices due to experience or specialized skills; on the other hand, a large buyer might be willing to pay higher prices to in-license drugs if there are substantial economies of scale and/or scope in R\&D. We include firm sizes, measured as the enterprise value for public companies (market value of the equity plus book value of debt) and the post-money valuation at the most recent round of venture capital financing for private firms. The expected sign on the size of the buyer is ambiguous a priori.

Lerner and Tsai (2000) show that biotechnology companies transfer a greater number of property rights (e.g., control of the clinical trials) to pharmaceutical companies when it is difficult or expensive to raise money from public and private equity markets. However, a more efficient adjustment to a shift in bargaining power would be for biotech companies to accept smaller deal payments when the cost of equity is relatively high. We include the cumulative amount of financing raised by biotechnology companies from public and private equity markets in each year, indexed relative to a base year (1996) to measure the state of the equity markets. To test whether small biotech companies are particularly vulnerable when the equity markets are "closed" or when equity financing is expensive, we interact the equity index with the selling firm's enterprise value in some specifications.

The data available to us on biotech-pharmaceutical company deal prices are not ideal for testing whether prices paid at certain stages of drug development are systematically biased, after controlling for costs, risks and the characteristics of drugs. Since we do not have good estimates for these parameters, our conclusions regarding bias in deal prices by stage of development will be preliminary and 
approximate. Similarly, we lack the data to test whether biotech firms with low quality drugs are forced to sign late-stage deals, when information costs are lower. This would require showing that deal payments for late-stage drugs are too low given the relatively high probability of reaching the market and the magnitude of sunk development costs relative to early-stage drugs. Deal payments typically include several components, including upfront payments of cash and investments in the selling firm's equity; milestone payments (payments conditional on the drug achieving certain designated events); sponsored research payments (usually a fixed amount per Ph.D. scientist assigned to perform research on the drug in question); post commercial payments (usually a royalty percent of gross sales or a percent of profit); and sometimes a "quid" in the form of rights to another product from the buyer (usually for late stage deals). A complete evaluation of the deal value requires data on each of these components, the rights and responsibilities transferred and retained (e.g. territories and therapeutic categories covered), and the probabilities that contingent payments will be made.

The valuation data available to us are the total potential pre-commercial payments from the buyer to the seller, where "potential" refers to the scenario where all contingent payments are made. This figure thus includes upfront payments, sponsored research payments, investments in the selling firm's equity as if it were cash, and any potential milestone payment. The total potential pre-commercial payment measure excludes post-commercial royalty payments, any cost sharing, and the value of any product swaps (quids). Since this total pre-commercial measure of the deal value incorporates milestone payments as equivalent to cash, without discounting for uncertainty or the time value of money, we expect it to be invariant by stage of the deal, except to the extent that: 1) the rights transferred differ by stage of deal; 2) bargaining power and hence the division of any surplus differs by stage of deal; 3) the absolute amount of the total deal value that is paid in pre-commercial versus royalty payments differs by deal stage; or 4) the quality of products traded differs by stage of deal.

\section{b) Effect of Deals on Firm Valuations}


If deals with pharmaceutical companies signal the quality of a biotech firm's product quality and managerial competence, the deal payments would represent only one component of the total value of a deal to a biotech firm. To test the signaling model we examine the impact of deals on the valuations that private biotech firms receive from venture capitalists and from the broader set of investors when the company goes public. Specifically, we regress the value of biotech company $j$ after the $n^{\text {th }}$ round of financing $\left(\mathrm{Y}_{\mathrm{jn}}\right)$ on an indictor variable that equals one if the company had signed one deal prior to the financing round $\mathrm{n}\left(\mathrm{D}_{\mathrm{n}}^{1}\right)$, and an indicator variable that equals one if the company had signed two or more such deals prior to financing round $n\left(\mathrm{D}^{2+}{ }_{\mathrm{n}}\right)$ :

$$
\text { (4) } \log \left(Y_{\mathrm{jn}}\right)=\alpha_{0}+\alpha_{1} \mathrm{D}_{\mathrm{jn}}^{1}+\alpha_{2} \mathrm{D}^{2+}{ }_{\mathrm{n}}+\alpha_{3} \mathbf{T}_{\mathbf{t}}+\alpha_{4} \mathbf{N}_{\mathbf{n}}+\mathrm{u}_{\mathrm{jn}}
$$

The market value of a firm is defined as the product of its shares outstanding and the price per share at the conclusion of a private-equity financing round, or at the time of the initial public offering (IPO). Separate indicators are included for the each round of venture capital financing and the company's initial public offering (n) and the year $(\mathrm{t})$ in which the financing occurred. The financing round variables measure the market value of a firm's experience.

In scenario 1 of the signaling model described in section 2 , the incremental value of partnering is large relative to the cost of distinguishing high- from low-quality biotech firms, so both high- and lowquality biotech firms sign early-stage deals. In this scenario $\alpha_{1}$ (and $\alpha_{2}$ ) could be positive or negative, depending on the number of high- versus low-quality biotech firms who sign deals, and the magnitude of under and over valuation in the pooling equilibrium that prevailed before deals were signed. In scenarios 2 and 3, only high-quality biotech firms sign early-stage deals, so $\alpha_{1}$ measures $V_{H}^{F}-V_{L}^{F}$-- the difference in the market value of high- and low-quality biotech companies once the quality signal has been received. In the gains-from-trade model, $\alpha_{1}$ (and $\alpha_{2}$ ) is predicted to be zero if the deal values on average are equal to the value of assets transferred; it is positive only if sellers on average capture some of the incremental 
value created by the alliance, and the incremental value of the deal is not already anticipated by equity markets.

One criticism of equation (4) is that $\alpha_{1}$ and $\alpha_{2}$ might not measure the incremental signal value of a deal's announcement only, but also any characteristic that is correlated with a firm's value that is unobserved to the analyst but observed by venture capitalists. For example, firms with capable managers and scientists might produce high-quality drugs, sign deals with pharmaceutical firms, and receive relatively high valuations from venture capitalists, but this does not imply a causal relationship for the deal signal.

To focus on the incremental value of the deal announcement, we also estimate a first-difference version of equation (4). Specifically, we regress the percentage change in a biotech company's value between financing round $\mathrm{n}-1$ and $\mathrm{n}$ on an indicator variable that equals one if the company signed its first deal between these two financing rounds $\left(D_{j, n \_n-1}^{1}\right)$, an indicator variable that equals one if the company signed a deal between these two financing rounds and it had already signed a deal prior to round n-1 (both $\mathrm{D}_{\mathrm{j}, \mathrm{n} \_\mathrm{n}-1}$ and $\mathrm{D}_{\mathrm{j}, \mathrm{n}-1}$ are equal to one), and indicator variables for the round of financing (e.g., second venture capital round) and the year in which the financing occurred:

$$
\log \left(\mathrm{Y}_{\mathrm{j}, \mathrm{n}}\right)-\log \left(\mathrm{Y}_{\mathrm{j}, \mathrm{n}-1}\right)=\beta_{0}+\beta_{1} \mathrm{D}_{\mathrm{j}, \mathrm{n}_{-} \mathrm{n}-1}^{1}+\beta_{2} \mathrm{D}_{\mathrm{j}, \mathrm{n}_{-} \mathrm{n}-1}^{1} \mathrm{D}_{\mathrm{j}, \mathrm{n}-1}+\boldsymbol{\beta}_{\mathbf{3}} \mathbf{N}_{\mathbf{n}}+\boldsymbol{\beta}_{\mathbf{4}} \mathbf{T}_{\mathbf{t}}+\eta_{\mathrm{jn}}
$$

We also include a continuous variable for the number of months between the successive financing rounds. The first-difference model eliminates from the analysis any time-invariant, unobserved firm characteristic, such as the quality of a company's science and managerial talent. A positive coefficient on the deal variable in this specification would provide strong evidence that the change in a firm's market value is associated with the recently concluded deal.

\section{c) Drug Development Success Rates}


In the gains-from-trade model, deals are signed only if the expected value of the drug is greater if co-developed than if the biotech develops the drug independently. In the signaling model, deals are signed only if biotech firms reimburse pharmaceutical firms for the costs of producing information on the quality of the drug and the biotech firm's managerial capabilities (the latter costs occur only for early deals). Thus in these models there is no "lemons" problem: biotech companies cannot dump their inferior products on uninformed pharmaceutical firms. We test this assumption by examining whether the drugs that biotech firms develop in pharmaceutical alliances are as likely to advance to the next development stage as drugs developed independently by biotech companies.

The probability a drug will advance to the next development stage is a function of the quality of the drug, the effort exerted by the company or companies involved in the development, and the experience of the company or companies involved. We assume the probability that drug $i$ that is originated by company $\mathrm{j}$ will complete a human trial $(\mathrm{A}=1)$, conditional on beginning the trial, is a linear function of the characteristics of the drug $\left(\mathbf{X}_{\mathbf{i}}\right)$, the characteristics of the firm or firms involved in the development $\left(\mathbf{F}_{\mathbf{j}}\right)$, and an indicator variable $\left(\mathrm{D}_{\mathrm{i}}\right)$ that equals one if the drug is being developed in an alliance of two or more firms:

$$
\operatorname{Pr}\left(\mathrm{A}_{\mathrm{ij}}=1\right)=\varphi_{0}+\varphi_{1} \mathbf{X}_{\mathrm{i}}+\varphi_{2} \mathbf{F}_{\mathrm{jt}}+\varphi_{3} \mathrm{D}_{\mathrm{i}}+v_{\mathrm{ij}}
$$

A negative coefficient for $\varphi_{3}$ is consistent with a lemons problem in the market for deals and/or moral hazard, if each firm in an alliance invests suboptimal effort because they share the benefits of their investment with the partner firm. A positive coefficient for $\varphi_{3}$ is consistent with either no asymmetric information and moral hazard, or asymmetric information and moral hazard problems that are overwhelmed by the positive benefits of co-development.

We perform three separate logit regressions for drugs that begin phase 1, phase 2, and phase 3 , where the dependent variable is one if a drug completes the trial, and zero otherwise. We include 13 
indicator variables for the therapeutic class of the drugs. Asymmetric information is likely to be most severe for small, relatively new biotech firms. We include in equation (6) separate indicator variables for companies that originated three or fewer drugs during our sample period, between four and 24 drugs, and 25 or more drugs. We also include interaction terms between the firm-size indicators and the codevelopment indicator $\left(\mathrm{D}_{\mathrm{i}}\right) .^{11}$

Some of the drugs are censored in that we do not directly observe the termination of R\&D projects; rather, we observe whether a drug advances to the next development phase. Drugs that had not been launched by 2000 , the final observation period in our data set, are right-hand censored. To address this censoring, we calculate the maximum length of time required for drugs in our sample to complete each development stage (five years for phase 1, five years for phase 2, and four years for phase 3). Drugs that are right-censored and started a stage beyond these time periods are assumed to have failed (coded as zero); right-censored drugs that started a phase within these time periods are omitted from the regressions rather than coded as zero.

\section{Data}

We use data from four major sources. The Windhover Database of Strategic Alliances contains information on pharmaceutical and biotechnology deals. It records information on all strategic alliance deals signed between by biotechnology and pharmaceutical companies between 1991 and 2000, to the extent that information is publicly available. The dependent variable in our analysis of deal payments (the deal price) is defined as the total potential pre-commercial payments from the licensee (biotech firms) to the licensor (pharmaceutical firm). "Potential" refers to the scenario where all scientific milestones are achieved. This figure includes upfront payments, sponsored research payments (usually a fixed amount per Ph.D. scientist assigned to perform research on the drug in question), investments in the licensor firm's equity, and potential milestone payments if designated events are achieved (e.g., initial phase 3

\footnotetext{
${ }^{11}$ In the regression we omit the co-development indicator and include the three firm-size indicators and the interactions of the co-development indicator and the three firm-size indicators.
} 
trial). Post-commercial royalty payments that the licensee may receive once the drug actually reaches the market are not included in the pre-commercial deal price.

Our measure of the deal price thus overstates the expected pre-commercial payments because it includes contingent milestone and sponsored research payments as if they will paid with certainty. Furthermore, equity investments by the licensee are included in the deal price although one could argue that the licensor is giving up an equally-valued asset in return - ownership in their firm. On the other hand, our measure of deal price underestimates the expected post-commercial payments to the selling firm because royalty payments are excluded. The company that outlicenses a drug often receives between five and 10 percent of the gross sales of the drug in the form of royalty payments, with higher amounts for late stage deals. These expected royalty payments can be a substantial share of the total discounted expected value for some compounds.

Since the Windhover database includes all types of alliances but our theory applies to codevelopment deals, we apply a set of criteria to select single-product deals with an R\&D component. Specifically, we exclude: co-marketing deals that are signed after a compound has already been developed; transactions that involve multiple products or acquisitions of research divisions or entire companies; ${ }^{12}$ and deals for platform technologies that the buyer hopes to use to develop multiple compounds (e.g., access to a genomics database or a drug delivery method). These criteria yield 539 deals that have non-missing values for the pre-commercial deal price as well as the other independent variables. The Windhover database also contains information on the therapeutic category of the drug compound (e.g., gastrointestinal drugs), using a modification of the World Health Organization (WHO) codes.

Sample means and standard deviations are reported in Table 1. The mean pre-commercial deal value is $\$ 29.3$ million in 1996 dollars, with a maximum deal value in our data set of $\$ 457$ million. The standard deviation of deal price is larger than the mean, which indicates there is considerable variation

${ }^{12}$ Discovery stage deals often involve a family of compounds where there is a single lead product. We include these deals in the analytic sample. 
and right skewness in the deal price distribution. The majority of deals are signed when the compound is still in the preclinical stage (which includes the discovery stage for this analysis), and in 95 percent of deals the licensee is a biotech company. The majority of deals were also the first ever for the biotech companies, which is not surprising because many biotech companies were founded in the 1980 s and went public in the late 1980s and early 1990s, so would have products in development in the 1990s.

Mean deal values by stage of deal are reported in Table 2. Deal prices increase monotonically by stage of development; firms outlicensing drug compounds in phase 1, phase 2, and phase 3 receive deal prices that are slightly larger than early-stage deals. Since this total precommercial payment measure is not adjusted for risk or the time value of money, this trend by deal phase suggests that later stage deals involve either greater retention of responsibilities for the seller and/or greater seller bargaining power for late stage deals.

We use Adis International R\&D Insight Database to analyze the post-deal performance in clinical trials of drugs developed in biotech-pharmaceutical alliances relative to drugs that are developed independently. Adis collects information on all drugs under active research and development by the international pharmaceutical and biotech industries, including: the generic name of the compound, the company name, current development stage and development history, a description of adverse events and clinical trials, World Health Organization (WHO) therapeutic indication categories (e.g., nervous system drugs), and launch dates by country for approved drugs.

Financial information on public biotech and pharmaceutical companies is available from Compustat. We collected information on the enterprise value of the buying and selling companies in the year prior to the deal. For companies that were private at the time of the deal but have since gone public, we used the Recombinant Capital RDNA database to obtain the post-money value of company at the round of venture capital financing immediately prior to the deal in question. Since biotech firms carry little debt, the post-money value of private companies should be analogous to the enterprise value of public biotech companies. In our sample, buyer firms are about five times larger than sellers on average, 
as measured by market capitalization. The total amount of public and private equity capital that biotech firms raised for each year between 1988 and 2000 was obtained from several sources. We use total equity funds raised in the year prior to a deal as a measure of the extent to which biotech firms may be liquidity constrained.

Recombinant Capital has recorded the financing history of over 550 biotech firms from the time of their first venture capital investment through their initial public offering, if it had occurred by July of 2001. This information is from Securities and Exchange Commission (SEC) filings when the company goes public, or in some cases from SEC filings by the company that acquires another biotech firm. Our sample will not include, therefore, biotech firms that went out of business before going public or being acquired.

\section{Results}

\section{a) Determinants of Deal Values}

In the signaling model, biotech firms reimburse pharmaceutical firms for the cost of producing information because the biotech firms reap the benefits of the information. Inexperienced biotechs pay more to cover the firm-specific component of the information costs, which are no longer incurred once the managerial capabilities of a biotech firm are revealed to the market. In Table 3 we report coefficient estimates of the determinants of deal prices. The dependent variable is the logarithm of the total potential pre-commercial payments from the buyer/pharmaceutical firm to the seller/biotech, measured in thousands of 1996 dollars. In the first specification we include only characteristics of the drug compound (indicator variables for therapeutic category and indicator variables for the compound's development stage at the time of the deal). Three of the 19 coefficients on the therapeutic category indicator variables (gastrointestinal, dermatology, and dental) are significantly lower at the 10-percent level than for other compounds (coefficients not shown in Table 3). Compounds can be assigned to multiple therapeutic categories so there is no single omitted category. When the selling firm retains the right to develop and 
sell the drug in the United States, it receives a 33 percent lower price than if it grants worldwide rights to the buyer. This is slightly lower than the U.S. share of total world pharmaceutical sales, which is around 40 percent. The coefficients on the phase 2 and phase 3 indicator variables are positive but not significantly different from zero.

In the second specification of Table 3 we add information on the structure of the deal (e.g., whether the deal included an investment by the buyer in the selling firm's equity), the experience of the selling firm, and the opportunity cost of alternative financing, measured by total biotech public and private equity financing in the year preceding the deal. We include two variables to measure the seller's experience: an indicator that equals one if this is the firm's first deal and an indicator that equals one if this is the firm's second deal (two or more prior deals is the omitted variable). Firms that are negotiating their first deal receive payments that are 60.2 percent lower ( $\$ 17.6$ million), on average, than firms with at least two prior deals. This discount for inexperience declines to 31.0 percent for the second deal. ${ }^{13}$ The coefficient on the first-deal variable is significantly different from zero at the one-percent level, whereas the coefficient on the second deal variable is significantly different from zero at the 13-percent level. These results suggest that pharmaceutical firms incur substantial costs to distinguish a high- from a lowquality start-up biotech firm. As shown below, the value of the signal to biotech firms (\$13.9 million in the first-difference specification of Table 6) is similar in magnitude to the implicit payment these firms make for producing the information, which implies that biotech firms are rational.

An alternative explanation for the negative coefficients on the first- and second-deal variables is that as biotech firms learn, the incremental value of co-developing a drug with a pharmaceutical firm decreases. If pharmaceutical firms capture the incremental value of co-development (synergies) due to greater negotiating power, then deal payments will be relatively small for inexperienced biotech firms. The two explanations need not be mutually exclusive; deal payments might increase with the seller's experience due to both learning and signaling. We would need more specific data on the rights and

\footnotetext{
${ }^{13}$ We also tried a specification including indicator variables for 3 and 4 prior deals, but these coefficients were insignificant.
} 
responsibilities of the companies involved in the alliances in order to separately measure the effect of the two alternative explanations.

Prices for phase 2 and phase 3 deals are 50 percent and 36 percent higher, respectively, than for deals where the compound is in the discovery or preclinical stage (the omitted category), controlling for drug and deal characteristics. Since we expect total potential pre-commercial payments to be invariant by stage of deal, the increase in deal prices for phase 2 and phase 3 deals is consistent with biotech firms taking on greater responsibilities in later stage deals (and therefore being reimbursed at a higher rate from the buyer); higher unobserved quality of late stage products; and/or greater bargaining power by biotech companies on later-stage drugs due to a relatively small number of sellers. The coefficient on the index of biotech funds raised from the equity markets is positive but not significantly different from zero.

In the third column of Table 3 we interact both the first-deal and second-deal indicator variables for the selling firm (omitted category is two or more prior deals) with the drug's stage of development at the time of the deal. The coefficients on the interaction between the first-deal variable and phase 1 and phase 3 are negative and very large, and the coefficients on the phase 1 and phase 3 development stage indicators are considerably larger than before. A biotech firm signing its first deal in phase 1 or phase 3 receives much smaller payments than a firm signing its first deal in the discovery or preclinical stages. The coefficients on the three second-deal interactions, which are not reported in Table 3, are insignificant. Setting the drug and firm characteristics at the sample mean values, a biotech firm that has already negotiated two alliances is predicted to receive a payment of $\$ 37.9$ million for a phase 3 deal versus $\$ 15.6$ million for a preclinical deal. By contrast, a biotech company that signs its first deal on a phase 3 drug receives payments that are about as large as a company that negotiates its first deal on a drug in the preclinical stage.

These results are consistent with scenarios 2 and 3 of the signaling model, where biotech firms with low-quality products cannot afford to reimburse a pharmaceutical firm for its information costs until the later development stages when the cost of producing information is relatively low. The small deal 
payments to inexperienced firms for phase 1 and phase 3 drugs, relative to firms that have already signed alliances, reflects the low quality of the drugs. This poor quality is unobserved to us, but is inferred by the prospective buyers because the biotech firm was unable to sign a deal early in the drug's development history.

In Table 4 we add firm-specific financial information on the sellers and buyers to further examine whether liquidity constraints and/or bargaining power affect deal payments. The coefficient on the seller's enterprise value is positive as expected, but not significant. The coefficient on the indicator variable for selling firms with missing financial information, which are predominantly private biotech companies and small public biotechs, is also not significantly different from zero. The coefficient on the equity index is positive but insignificant, as before. Thus we find little evidence that the status of the equity markets affects deal payments, even for small biotechs that are more likely to be cash constrained. Combining these results with those from Lerner and Tsai (2000), this suggests that liquidity constraints lead to adjustment in rights transferred rather than in the price paid for those rights, contrary to what might be expected under the efficient markets hypothesis.

The coefficient on the buying firm's enterprise value is positive and significant, implying that large pharmaceutical firms pay more to inlicense compounds than small firms. A $\$ 1$ billion increase in a buyer's market capitalization is associated with a 1.8 percent increase in the deal payment. This result is consistent with the presence of economies of scale and scope in R\&D which allow larger pharmaceutical firms to outbid smaller firms when inlicensing compounds. It may also reflect unobserved quality, if larger firms only bid for those products that have relatively large expected revenues. In this specification, deal payments for phase 2 drugs were 45 percent larger than deals for preclinical drugs. As before, we interpret this increased payment as evidence that the selling firm will take greater responsibility in the subsequent development of the drug.

\section{b) Effect of Deals on the Valuation of Firms}


If alliances with pharmaceutical firms allow private biotech firms to signal the quality of the firm's product pipeline and management to venture capitalists, then alliances are predicted to cause an increase in the market value of a firm. We present some descriptive data in Table 5 on the venture capital financing history and initial public offerings (IPOs) of 566 biotech firms, as reported by Recombinant Capital. Biotech firms typically raise several rounds of private equity from venture capital firms before going public or being acquired. As displayed in the final column of Table 5, 58 percent of the biotech firms in the data set raised between three and five rounds of private equity financing.

The mean market value of a biotech firm after its first round of venture capital financing was $\$ 11.1$ million, and the value more than doubled by the second financing round (second column of Table 5). Values continue to grow between venture capital rounds, although at decreasing rates in percentage terms. Three-quarters of these 566 firms had gone public by 2001. As reported in the first column of Table 5, few biotech firms had signed any deals prior to their first round of private-equity financing. By the time of the initial public offering, about one-sixth of the biotech firms had formed at least one alliance. If deals function as signals of private firms' quality, therefore, they are probably not the only signaling mechanism. Of the 90 firms that signed a deal prior to their IPO, 82 percent signed one deal only, 10 percent signed two deals, and only 8 percent signed three or more deals.

We present the results of the valuation regressions in Table 6. In the first specification the dependent variable is the logarithm of the firm's value at the conclusion of a financing round, measured in millions of dollars. ${ }^{14}$ Valuations at each venture capital round and the IPO, if it occurred, are pooled together. We adjust the standard errors to allow the error terms to be correlated within a firm across the different financing rounds. Biotech firms that had signed a single deal received valuations that were 38.0 percent higher, and biotech firms that had signed two or more deals received valuations that were 39.2 percent higher, on average, than firms that had not yet signed a deal (the omitted variable). The mean biotech valuation across all financing rounds in the sample was $\$ 59.9$ million, so the estimated valuation premium associated with signing a deal is about $\$ 22.8$ million. We cannot reject the hypothesis that the 
coefficients on the one-deal and two-plus deal coefficients are equal, which suggests that one deal is sufficient to signal a biotech firm's quality. With symmetric information a biotech company's second deal should not affect its value because the deal payment will be commensurate with the value of the assets exchanged.

The coefficient on the second venture capital round variable indicates that the value of biotech firms at the end of the second financing round are 96 percent higher than in the first round (the omitted round), on average. Values increase monotonically over the subsequent private equity rounds and the initial public offering. We control for the year of financing but do not report the coefficients in Table 6 . Market values increased substantially in the late 1990s and in 2000. Relative to 1991, biotech valuations were 30 percent higher in real terms in 1997, 41 percent higher in 1998, 74 percent higher in 1999, and 118 percent higher in 2000 .

The second column of Table 6 presents results of the first-difference valuation regression (as described by equation 5). Time-invariant characteristics that are correlated with a firm's value drop out of the first-difference specification, so we should obtain a more precise measure of the incremental signal value of a deal. A biotech firm signing its first deal experiences an estimated 23.2 percent increase in value, on average, at its subsequent financing round relative to biotech firms that did not sign a deal in the interim. This result increases our confidence that the step-up in a biotech firm's market value can be attributed to the relatively recent deal signing. The coefficient from the first-difference specification is smaller than the estimated impact of deals from the cross-section regression, but is still significantly different from zero and economically meaningful. Based on this estimate, a biotech firm would receive a $\$ 13.9$ million higher valuation due to the positive signal of forming an alliance with a pharmaceutical firm. The coefficient on a deal other than the biotech firm's first deal is positive but not significantly different from zero, which is consistent with the cross-section regression where the coefficient on the first-deal and two-plus deal variables are essentially the same. This implies that it takes only one deal to signal a biotech firm's quality to private investors; subsequent deals should have no impact on a firm's

\footnotetext{
${ }^{14}$ Deal prices are converted to 1996 dollars using the producer price index.
} 
valuation once information ceases to be asymmetric. There are only 16 deals in our data by firms that have already signed a deal, so the lack of significance may be due to a small sample.

These results are consistent with scenarios 2 and 3 of our model, where pharmaceutical firms sign co-development deals with high-quality biotech firms only. The signal from the deal allows high-quality and low-quality firms to be valued appropriately by venture capitalists. The $\$ 13.9$ million premium associated with a deal measures the difference in the value of a high- and low-quality firm $\left(\mathrm{V}^{\mathrm{F}}{ }_{\mathrm{H}}-\mathrm{V}_{\mathrm{L}}^{\mathrm{F}}\right)$, once investors can distinguish the two quality types. We cannot rule out scenario 1 , however, where all biotech companies sign deals and venture capitalists infer the quality of firms from the magnitude of the deal payments. In this latter scenario, the coefficient on the deal variables in Table 6 indicate that there are more high- than low-quality firms signing deals, and/or the magnitude of the under valuation of firms in the previous pooling equilibrium exceeded the magnitude of the over valuation.

The results from the valuation analysis suggest that gains-from-trade in co-development is not the sole rationale for deals. If it were, and if venture capitalists anticipated that firms would enter into deals when deals are efficient, the realization of such alliances would have no effect on firm valuations. Our valuation analysis focuses on private biotech firms because that is where we think information asymmetry problems might be particularly acute.

\section{c) Post-deal Performance}

We use data on development success to examine whether drugs that are jointly developed by two or more companies are more or less likely to advance to the next stage of development, relative to drugs that are developed independently by pharmaceutical and biotech companies. If biotech firms take advantage of their informational advantage to outlicense their low-quality drugs, then drugs that are codeveloped should be less likely to advance (Pisano, 1997). The implication of this possible information asymmetry - biotechs with inferior products form alliances - is an alternative explanation for our finding that biotechs signing their first deal receive substantially discounted payments. Conversely, if the market 
for deals allows pharmaceutical firms to distinguish high- and low-quality drugs, then drugs that are codeveloped should be just as likely to advance as those developed independently. Finally, if there are benefits of co-development (gains-from-trade model) and/or if only high-quality drugs are outlicensed (scenarios 2 and 3 of the signaling model), then drugs that are co-developed should be more likely to advance than those developed independently.

In Table 7 we present selected coefficient estimates from three different logit regressions using the Adis database of drugs under development by biotech and pharmaceutical firms. The first regression includes all drugs that began a phase 1 trial. Each observation is a condition for which a drug is being tested, so there may be multiple observations for a particular drug. The dependent variable takes the value one if phase 1 is completed and a phase 2 trial is initiated for the condition in question, and zero otherwise. To control for firm experience, we include separate indicator variables for companies that originated three or fewer drugs during the sample period (1991-2000), between four and 24 drugs, and 25 or more drugs. Biotech firms are in the small- or medium-sized category whereas most pharmaceutical firms are in the largest category. We interact the three dummy variables for firm size with an indicator variable if the drug is being co-developed. Recall that a majority of deals in our data set (61 percent) represent the first deal signed by a biotech company, so most of the alliances involve inexperienced biotech firms.

In the first column, the three coefficients on the co-development interaction variables are positive and significant; compounds being developed through an alliance are more likely to complete phase 1 trials than compounds developed independently by small, medium, or large firms. These coefficients are also economically meaningful. A drug originated by a medium-sized firm that is co-developed has a probability of completing a phase 1 trial that is an estimated 12.5 percentage points higher than an otherwise similar drug (i.e., same therapeutic category) that the firm develops independently (marginal effects of co-development are reported in the bottom row of Table 7). Thus contrary to Pisano (1997), we find no evidence that biotech firms use their informational advantage relative to prospective buyers to 
outlicense relatively unattractive compounds. Our results are consistent with a situation where lowquality drugs are less likely to be outlicensed because their parent firms cannot reimburse pharmaceutical firms for the information costs (scenarios 2 and 3 of the signaling model), and/or the collaboration between multiple companies improves the likelihood a drug will advance.

The last two columns of Table 7 report similar logit regressions for drugs that began phase 2 and phase 3 clinical trials. The dependent variable in each specification is one if the drug successfully completed that single stage. As before, the coefficients on the co-development interactions are positive and significant. The predicted probability that a drug originated by a small firm and developed jointly with another company will complete phase 2 and phase 3 trials is 17 and 30 percentage points higher, respectively, relative to a drug the firm originates and develops independently. We find no evidence, therefore, that the lower payments accepted by inexperienced biotech companies are due to the greater scientific risk of the product.

\section{Conclusions}

The analysis in this paper sheds light on several hypotheses regarding the effects of buyer and seller characteristics, liquidity constraints, and asymmetric information in the market for biotechpharmaceutical deals. We find that biotechnology companies receive a 60 percent discount for their first deal and a 30 percent discount for their second deal, and that these discounts are not consistent with the post-deal performance of these drugs. These discounts are consistent with a model in which one function of deals from the seller's perspective is to signal to equity markets the value of the firm's products and management. Pharmaceutical companies are plausibly better able to evaluate the quality of a biotech company's assets and the capabilities of its management than pure financial intermediaries. The discounted payments accepted by inexperienced biotech firms represent implicit payments to reimburse the pharmaceutical company for the cost of producing information. Since a pharmaceutical company takes not only an equity stake in a small firm but also acquires rights to the assets, the pharmaceutical 
firm may have stronger incentives to invest optimally in information gathering than a venture capitalist that takes only a partial and temporary equity share. The fact that drugs in biotech-pharmaceutical alliances perform better in subsequent trials than products developed solely in-house by biotech or pharmaceutical firms confirms that co-development adds value that is sufficient to outweigh any moral hazard problems that result from sharing development responsibilities. These findings are inconsistent with the lemons hypothesis, that biotech companies are able to outlicense their least promising drugs due to asymmetric information. Our finding that the discount for first deals does not decline or disappear for later-stage drugs, when more objective information is available, provides further evidence against the lemons hypothesis.

Although biotech companies take a substantial discount on their first deal, this nevertheless appears to be rational because a deal with a pharmaceutical company sends a positive signal to prospective investors. We find that biotech firms that have signed a deal receive substantially higher valuations from venture capitalists and other investors at subsequent financing rounds. The magnitude of this premium (between $\$ 13.9$ million and $\$ 22.8$ million) roughly offsets the discounted deal payments accepted by inexperienced biotech firms ( $\$ 17.6$ million). This evidence of positive effects of deals on subsequent financing is more consistent with the signaling model than with the simple gains-from-trade model. However, the fact that even established biotech firms continue to do deals suggests that deals can provide a means to take advantage of differing expertise to increase real productivity, as well as their information-producing, signaling function.

Several important and intriguing questions are not addressed here, due to limitations of our data on rights transferred and post-launch payments. Our data do not permit us to determine whether the full prices paid for deals at different stages of drug development are fair, given differences in costs, rights and risk transferred. The data also do not enable us to determine how deal values change with the bargaining power of the parties, in particular, whether biotech sellers having greater bargaining power when they bargain for relatively scarce, late stage compounds than when they bargain for the more numerous 
preclinical compounds. If deal values do vary systematically by stage of deal, adjusting for costs and risks, this would suggest unexploited profit opportunities and raise the question of why pharmaceutical firms do not anticipate the premium for late-stage deals and switch more of their demand to middle or early stage deals, thereby arbitraging away the late stage premiums. We plan to address these questions in future work. 


\section{References}

Aghion, P. and Jean Tirole, 1994, "On the Management of Innovation," Quarterly Journal of Economics 109: 1185-1207.

Akerlof, George, 1970, “The Market for 'Lemons': Quantitative Uncertainty and the Market Mechanism,” Quarterly Journal of Economics 84: 488-500.

Campbell, Tim S., and William A. Kracaw, 1980, "Information Production, Market Signalling, and the Theory of Financial Intermediation," The Journal of Finance 35(4): 863-882.

Chan, Yuk-Shee, 1983, "On the Positive Role of Financial Intermediation in Allocation of Venture Capital in a Market with Imperfect Information," The Journal of Finance 38(5): 1543-1568.

Chemmanur, Thomas J., 1993, "The Pricing of Initial Public Offerings: A Dynamic Model with Information Production,” The Journal of Finance 48(1): 285-304.

Chemmanur, Thomas J., and Paolo Fulghieri, 1994, "Investment Bank Reputation, Information Production, and Financial Intermediation," The Journal of Finance 49(1): 57-79.

DiMasi, Joseph A., "New Drug Innovation and Pharmaceutical Industry Structure: Trends in the Output of Pharmaceutical Firms," Drug Information Journal 34: 1169-1194.

Grossman, Sanford J., 1976, "On the Efficiency of Competitive Stock Markets When Traders Have Diverse Information," Journal of Finance 31(2): 573-585.

Grossman, Sanford J., and Joseph E. Stiglitz, 1976, "Information and Competitive Price Systems," American Economic Review 66(2): 246-253.

Kogut, Bruce, 1988, "Joint Ventures: Theoretical and Empirical Perspectives," Strategic Management Journal 9: 319-332.

Leland, Hayne E., and David H. Pyle, 1977, "Informational Asymmetries, Financial Structure, and Financial Intermediation," The Journal of Finance 32(2): 371-387.

Lerner, Josh and Alexander Tsai, 2000, "Do Equity Financing Cycles Matter? Evidence From Biotechnology Alliances," NBER Working Paper number 7464.

Lerner, Josh and Robert P. Merges, 1998, "The Control of Technological Alliances: An Empirical Analysis of the Biotechnology Industry," The Journal of Industrial Economics 46(2): 125-156.

Longman, Roger and Kevin Roche, 1997, "Biotech Deals by the Numbers," In Vivo, September 1997.

Pisano, Gary, 1997, "R\&D Performance, Collaborative Arrangements, and the Market-for-Know-How: A Test of the 'Lemons' Hypothesis in Biotechnology," mimeo. 
Table 1

Sample Means and Standard Deviations $(\mathrm{n}=539)$

\begin{tabular}{|c|c|c|}
\hline$\underline{\text { Variable }}$ & $\underline{\text { Mean }}$ & $\begin{array}{l}\text { Standard } \\
\text { Deviation }\end{array}$ \\
\hline Pre-commercial value of the deal (\$millions) $)^{15}$ & 29.3 & 37.1 \\
\hline \multicolumn{3}{|l|}{ Development stage of compound at time of deal: } \\
\hline Preclinical & 0.616 & 0.487 \\
\hline Phase 1 & 0.079 & 0.270 \\
\hline Phase 2 & 0.121 & 0.327 \\
\hline Phase 3 & 0.147 & 0.354 \\
\hline First deal for seller & 0.610 & 0.488 \\
\hline \multicolumn{3}{|l|}{ Seller retains rights to: } \\
\hline - US market & 0.252 & 0.434 \\
\hline - Japanese market & 0.270 & 0.444 \\
\hline Deal includes an equity investment & 0.472 & 0.500 \\
\hline Reverse licensing deal & 0.026 & 0.158 \\
\hline $\begin{array}{l}\log (\text { public and private equity raised by biotech } \\
\text { companies in year prior to deal, } \$ \text { millions })\end{array}$ & 4.68 & 0.645 \\
\hline $\begin{array}{l}\text { Seller's enterprise value (market value of equity }+ \\
\text { book value of debt) in year prior to deal, } \\
\text { \$millions }{ }^{16}\end{array}$ & 2216 & 11527 \\
\hline Seller's enterprise value is missing & 0.333 & 0.413 \\
\hline $\begin{array}{l}\text { Buyer's enterprise value in year prior to deal, } \\
\text { \$millions }{ }^{17}\end{array}$ & 10782 & 21982 \\
\hline Buyer's enterprise value is missing & 0.218 & 0.470 \\
\hline
\end{tabular}

\footnotetext{
15 Pre-commercial deal value is the sum of the upfront payments, sponsored research payments (usually an amount per scientist assigned to the compound), milestone payments, and equity investments.

${ }^{16}$ The mean presented for the seller's enterprise value is for the subset of 360 publicly-traded firms whose financial data are recorded by Compustat.

${ }^{17}$ The mean presented for the buyer's enterprise value is for the subset of 421 publicly-traded firms whose financial data are recorded by Compustat.
} 
Table 2

\section{Number of Deals and Deal Payments by Development Stage}

\begin{tabular}{|c|c|c|c|c|}
\hline & Pre-clinical & Phase 1 & Phase 2 & Phase 3 \\
\hline $\begin{array}{l}\text { Mean observed deal } \\
\text { payment (\$million in } \\
1996 \text { dollars) }\end{array}$ & $\$ 27.0$ & $\$ 29.4$ & $\$ 37.7$ & $\$ 33.0$ \\
\hline Number of deals & 334 & 43 & 66 & 80 \\
\hline
\end{tabular}

Source: Windhover Database. 
Table 3: Coefficient Estimates on the Determinants of Deal Values

\begin{tabular}{|c|c|c|c|c|c|c|}
\hline$\underline{\text { Variable }}$ & $\underline{\text { Coefficient }}$ & S.E. & $\underline{\text { Coefficient }}$ & S.E. & $\underline{\text { Coefficient }}$ & S.E. \\
\hline \multicolumn{7}{|l|}{ Stage of drug at time of deal: } \\
\hline - Phase 1 & -0.040 & 0.245 & -0.100 & 0.237 & 0.669 & 0.452 \\
\hline - Phase 2 & 0.335 & 0.207 & $0.497 * *$ & 0.206 & 0.387 & 0.369 \\
\hline - Phase 3 & 0.269 & 0.193 & $0.356^{*}$ & 0.188 & $1.24 * *$ & 0.426 \\
\hline \multicolumn{7}{|l|}{ Seller maintains rights to: } \\
\hline - US market & $-0.329 *$ & 0.185 & $-0.308^{*}$ & 0.181 & -0.261 & 0.180 \\
\hline - Japanese market & -0.189 & 0.183 & -0.150 & 0.177 & -0.169 & 0.177 \\
\hline Biotech equity raised, $t-1$ & & & 0.025 & 0.099 & 0.032 & 0.099 \\
\hline First deal for seller & & & $-0.602 * *$ & 0.160 & $-0.335^{*}$ & 0.202 \\
\hline Second deal for seller & & & $-0.310 * *$ & 0.202 & -0.276 & 0.254 \\
\hline \multicolumn{7}{|c|}{ First deal for seller interacted w/: } \\
\hline - $\quad$ deal signed in Phase 1 & & & & & $-1.11^{* *}$ & 0.542 \\
\hline - $\quad$ deal signed in Phase 2 & & & & & 0.144 & 0.452 \\
\hline - $\quad$ deal signed in Phase 3 & & & & & $-1.35^{* *}$ & 0.483 \\
\hline Constant & $9.56 * *$ & 0.208 & $9.77 * *$ & 0.556 & $9.55^{* *}$ & 0.562 \\
\hline $\mathrm{n}$ & 539 & & & & 539 & \\
\hline $\mathrm{R}^{2}$ & 0.07 & & 0. & & 0.17 & \\
\hline
\end{tabular}

Notes: Dependent variable: $\log$ (pre-commercial deal value in $\$ 000$ s), which includes upfront payments, sponsored research payments (usually an amount per scientist assigned to the compound), milestone payments, and equity investments. Nineteen indicator variables are included for the therapeutic category of the compound, using codes that Windhover adapted from the World Health Organization (WHO) codes. We omit the indicator variable for deals signed when the compound was in the discovery/pre-clinical stage of development. Interactions of the second deal variable and the three stages are included. Indicator variables are also included for deals that included an equity investment and for reverse licensing deals (except in column 1). **: significantly different from zero at the 5percent level; *: significantly different from zero at the 10-percent level. 
Table 4: Coefficient Estimates on the Determinants of Deal Values

Stage of drug at time of deal:

\section{Coefficient $\quad \underline{\text { Standard Error }}$}

- Phase 1

- Phase 2

$\begin{array}{ll}-0.116 & 0.229\end{array}$

$0.454 * * \quad 0.20$

- Phase 3

$0.346^{*} \quad 0.185$

Seller maintains rights to:

- US market

$-0.211$

0.177

- Japanese market

$-0.111$

0.172

First deal for seller

$-0.571 * *$

0.164

Second deal for seller

$-0.253$

0.197

Biotech equity raised, $\mathrm{t}-1$

0.043

0.096

Seller's enterprise value, $\mathrm{t}-1$

0.0102

0.00722

Indicator if missing enterprise

0.162

0.136

value for seller

Buyer's enterprise value, $t-1$

$0.0178 * *$

0.0029

Indicator if missing enterprise

0.380 **

0.134

value for buyer

Constant

$9.13^{* *}$

0.555

n

$\mathrm{R}^{2}$

0.21

Notes: Dependent variable: $\log ($ pre-commercial deal value in $\$ 000 \mathrm{~s})$. Nineteen indicator variables are included for the therapeutic category of the compound, using codes Windhover adapted from the World Health Organization (WHO) codes. We omit the indicator variable for deals signed when the compound was in the discovery/preclinical stage of development. Indicator variables are also included for deals that included an equity investment, and for reverse licensing deals. Buyer and seller enterprise values are measured in \$billions.

**: significantly different from zero at the 5-percent level

*: significantly different from zero at the 10 -percent level. 
Table 5

Alliance Activity and Private and Public Market Valuation of Biotech Firms

$$
(\mathrm{n}=566)
$$

Percentage of biotech firms that have signed

\section{Financing Round}

$$
1
$$$$
2
$$

3

4

5

6

$7-9$

Initial public offering

\begin{abstract}
a deal before the round
\end{abstract}

$$
1.2 \%
$$

$3.2 \%$

$5.1 \%$

$7.8 \%$

$10.7 \%$

$11.8 \%$

$12.3 \%$

$15.7 \%$
Mean valuation after

financing (\$millions)

$\$ 11.1$

$\$ 26.3$

$\$ 42.7$

$\$ 55.3$

$\$ 68.0$

$\$ 84.3$

$\$ 120.2$

$\$ 162.2$
Percentage of biotech firms for whom this is the final venture capital round ${ }^{18}$

Source: Recombinant Capital.

\footnotetext{
${ }^{18}$ Three-quarters of the firms in the Recombinant Capital data set had gone public by 2001, while the other firms had been acquired or are right-censored - we do not yet observe their final outcome. For censored firms we interpret their last observed financing round as their final round for descriptive purposes.
} 
Table 6: Impact of Deals on Biotech Venture Capital and Initial Public Offering Valuations

$$
\text { Dependent variable: } \begin{gathered}
\log (\text { company value } \\
\text { after financing round } n
\end{gathered} \quad \begin{gathered}
\log \left(\text { value }_{n}\right)-\log \left(\text { value }_{n-1}\right) \\
\text { (pct. change in company's value) }
\end{gathered}
$$

$\begin{array}{lc}\text { Biotech had signed } 1 \text { deal } & 0.380^{* *} \\ \text { prior to financing round } \mathrm{n} & (0.072) \\ & \\ \text { Biotech had signed } 2 \text { or more deals } & 0.392 * * \\ \text { prior to financing round } \mathrm{n} & (0.168)\end{array}$

Biotech signed their $1^{\text {st }}$ deal between

round $n-1$ and round $n$

Biotech signed a deal between round $n-1$

and round $n$, and it was not their $1^{\text {st }}$ deal

$2^{\text {nd }}$ venture capital round

$0.963 * *$

(0.042)

$3^{\text {rd }}$ venture capital round

$1.51 * *$

$4^{\text {th }}$ venture capital round

$1.76 * *$

(0.067)

$5^{\text {th }}-9^{\text {th }}$ venture capital round

$2.04 * *$

$(0.082)$

$2.59 * *$

(0.064)

Months between financing rounds

Constant

$1.76^{* *}$

(0.077)

2,477

0.59

$\mathrm{R}^{2}$
$0.232 * *$

(0.0817)

0.107

(0.124)

$-0.404 * *$

$-0.609 * *$

(0.055)

$-0.746 * *$

(0.049)

$-0.211 * *$

(0.054)

0.0011

(0.0014)

$0.984 * *$

(0.060)

1,883

0.17

(1)

\footnotetext{
$* *=$ significantly different from zero at the 5-percent level.

* = significantly different from zero at the 10-percent level.
}

Notes: the dependent variable in the first specification is the logarithm of a company's post-money valuation after a round of venture capital financing or in an initial public offering (IPO), measured in millions of dollars. The dependent variable in the second specification is the difference in the logarithm of the company's post-money valuation between subsequent rounds of venture capital financing, or between the final venture capital round and the IPO, also measured in millions of dollars. We include a set of indicators for the year of the financing and the financing round (the first venture capital round is omitted in the first specification, and the change in value between the first and second venture capital rounds is omitted in the second specification). 
Table 7: Coefficient Estimates of the Determinants of R\&D Success

Sample:

Dependent variable:
Drugs That Drugs That Drugs That Started Phase $1 \quad$ Started Phase $2 \quad$ Started Phase 3

$\underline{1 \text { if started } \mathrm{Ph} 2} \quad \underline{1 \text { if Started } \mathrm{Ph} 3} \quad \underline{1 \text { if approved by FDA }}$

Variable

Small company is originator:

- develop independently

0.221

$-0.371$

$-1.52 * *$

$(0.251)$

$(0.230)$

$(0.311)$

- co-develop

$0.466 *$

$0.734 * *$

$1.34 * *$

$(0.264)$

$(0.217)$

$(0.294)$

Medium-sized company is originator:

- develop independently

$-0.323$

$-0.724 * *$

$-1.01 * *$

$(0.230)$

$(0.220)$

$(0.277)$

- co-develop

$1.22 * *$

$1.35 * *$

$1.19^{* *}$

$(0.257)$

$(0.245)$

Large company is originator:

$(0.209)$

$-0.505^{*}$

$-0.551 * *$

$-0.513 * *$

$(0.259)$

$(0.223)$

$(0.203)$

$0.666^{* *}$

- co-develop

$1.13 * *$

$0.832 * *$

$(0.223)$

Constant

$1.13 * *$

(0.189)

$0.697 * *$

$(0.220)$

$0.529 * *$

$(0.218)$

Psuedo- $\mathrm{R}^{2}$

0.08

$(0.184)$

0.14

n

2,392

0.09

1,083

Marginal effect of co-

development on probability

of advancing for a:

- small firm

0.041

0.171

0.302

- medium-sized firm

0.125

0.310

0.288

* = significantly different from zero at the 10 percent level.

$* *=$ significantly different from zero at the 5 percent level.

Notes: Observations are specific conditions for which a drug is being developed to treat. Dependent variable is one if a drug advanced to the subsequent development stage or was approved by the FDA. The logit regressions include thirteen indicators for the therapeutic category of the compound. To address right-hand censoring, we calculate the maximum length of time it took for a drug to complete each development stage (five years for phase 1, five years for phase 2, and four years for phase 3). Drugs that were censored and had started a stage within these time periods were omitted from the regressions; drugs that were censored and had started a stage beyond these time periods were assumed to have failed. 
Figure 1

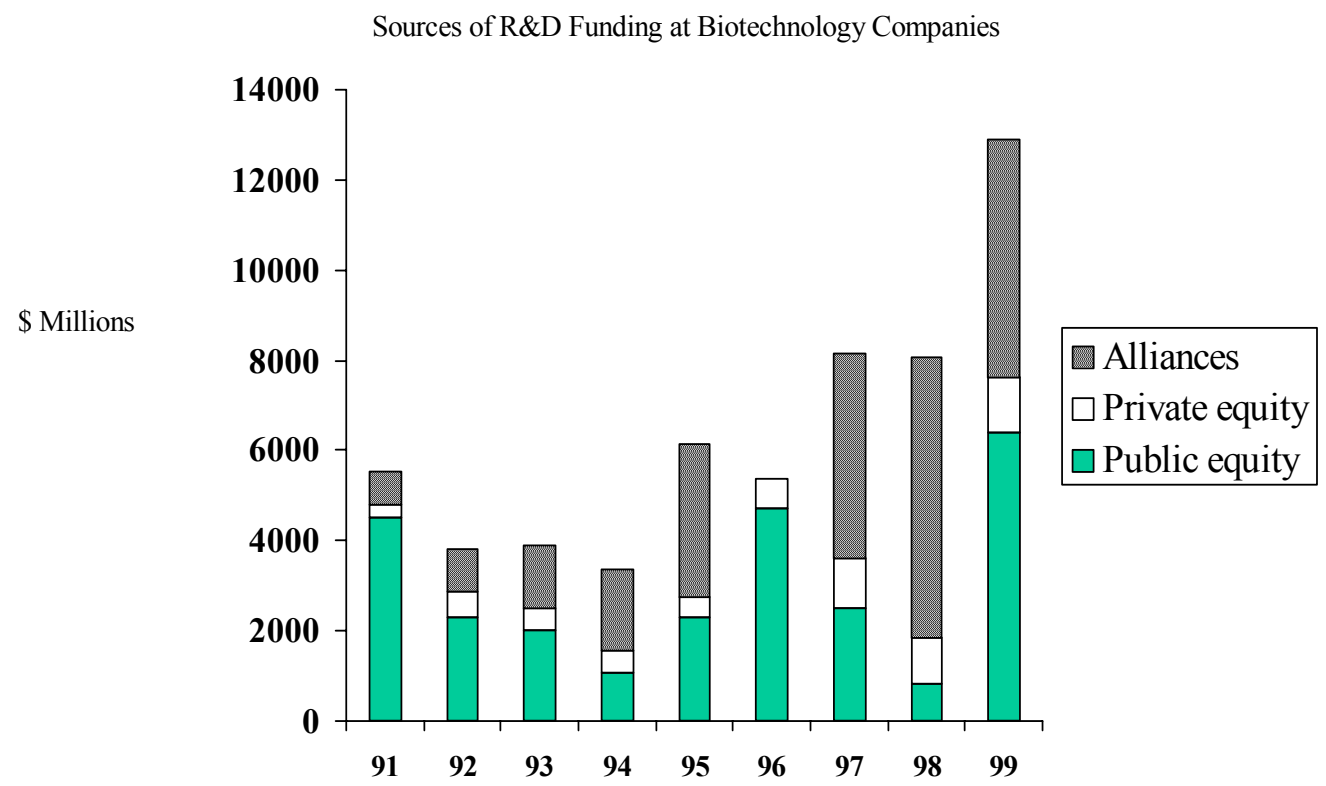

Alliance as $\%$ of total financing:

$\begin{array}{lllllllll}13 & 25 & 35 & 53 & 56 & -- & 56 & 77 & 41\end{array}$

Source: Lerner and Merges (1998); National Science Board; Recombinant Capital; Burrill \& Company. 
Figure 2

Number of Biotech Alliances by Phase and Year for the 20 Largest Pharmaceutical Companies

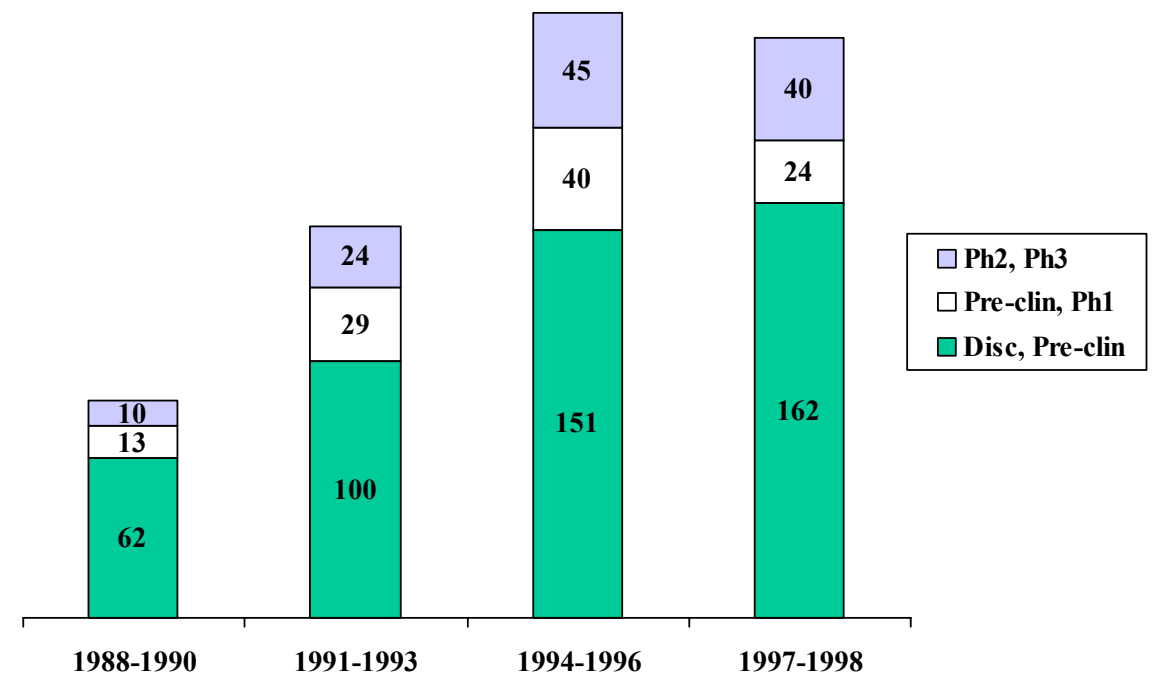

Source: Recombinant Capital RDNA Database. 